\title{
SD
}

409 ML 


$$
\approx
$$








\section{FOREST NURSERY}

AND REFORESTATION WORK

\section{MASSACHUSETTS}

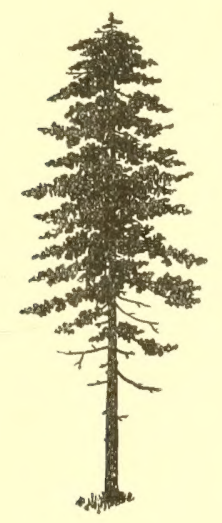

By R. S. LANGDELL, ASSISTANT

UNDER THE DIRECTION OF F. W. RANE, STATE FORESTER

BOSTON

WRIGHT \& POTTER PRINTING COMPANY, STATE PRINTERS

18 POST OFFICE SQUARE 


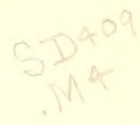

APPROVED BY

The State Board of Publication,

D. Of $D$. $A=12=19: 10$ 


\section{CONTENTS.}

Introduction, . . . . . . . . . . . . . 5

Acknowledgments, . . . . . . . . . . . . . 5

The forest nursery, . . . . . . . . . . . . . . 47

Procuring the seed, . . . . . . . . . . . . . 47

Layering seed in sand, . . . . . . . . . . . . . . . 8

Site for a nursery, . . . . . . . . . . . . . . . . . 9

Preparation for the seed beds, . . . . . . . . . . . . . . $\quad$. 9

Time to plant seed, . . . . . . . . . . . . . . . . . $\quad$. 9

A marker, . . . . . . . . . . . . . . . . . 10

Sowing the seed, . . . . . . . . . . . . . 10

Mulching, . . . . . . . . . . . . . . 10

Shading, . . . . . . . . . . . . . . . . 10

Damping off, . . . . . . . . . . . . . 11

Protection for the winter, . . . . . . . . . . . 11

Hardening off of evergreens, . . . . . . . . . . . 12

Transplanting, . . . . . . . . . . . . . . 12

Puddling, . . . . . . . . . . . . . . . . . 12

Heeling in young trees, . . . . . . . . . . . . 13

Root pruning, . . . . . . . . . . . . . . 13

Packing seedlings, . . . . . . . . . . . . . 13

Data on collecting and storing forest tree seeds, . . . . . . 14

Cost of seedlings and transplants per thousand, . . . . . . . 15

Reforestation, . . . . . . . . . . . . . . . 15

Cut-over land, . . . . . . . . . . . . . . . . . 15

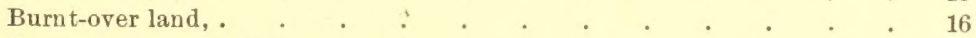

Run-out pasture land, . . . . . . . . . . . . . 16

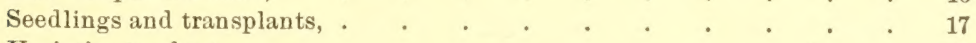

Varieties to plant, . . . . . . . . . . . . . . . 17

Trees suitable for forest planting in Massachusetts, . . . . . . 18

Nurserymen, . . . . . . . . . . . . . . . . . . 19

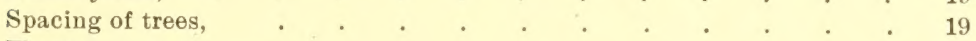

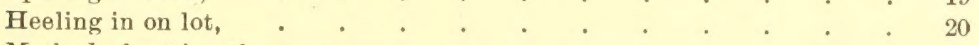

Method of setting the trees, . . . . . . . . . . . . 20

Time to plant, . . . . . . . . . . . . . . . 21

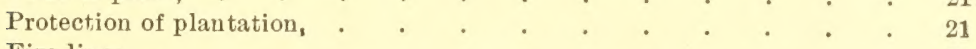

Fire lines, . . . . . . . . . . . . . . 21

Reforestation work done by the State, . . . . . . . . . . . 22

Reforestation act of 1908 (chapter 478), . . . . . . . . . . . 23

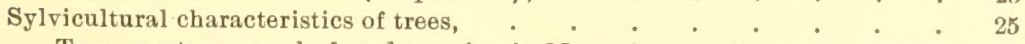

Trees most commonly found growing in Massachusetts, the uses to which their timber is put, and a few of their most important enemies, . . $\quad 25$

Application for examination of lands, . . . . . . . . . . . . 36 



\section{INTRODUCTION.}

The State Forester has been anxious to place in the hands of our people some definite information on forest nursery and reforestation work. It is believed that this bulletin will meet the requirements.

Nearly every farm in Massachusetts - in fact, in New England - has its woodlot, or some land suited only to the growing of trees. In most cases such land has been wholly or partly cut off or burned over, and left as barren, worthless tracts, an unsightly addition to the rest of the property.

It is the purpose of this bulletin to set forth a remedy which will bring these waste and denuded lands back into forest growth, and provide a method to keep them in a condition to be a source of revenue to the owner at a very small outlay. If, when a woodlot is cut off, provision is made for restocking it, either by natural reproduction, as the leaving of seed trees, or by replanting it with nursery-grown stock, much headway will be made towards bringing the waste lands of Massachusetts back into forest growth.

Nursery work and that of reforestation go hand in hand though two entirely separate undertakings. It is from the nursery that the young trees are furnished to be used on land to be restocked.

\section{ACKNOWLEDGMENTS.}

The work of writing and compiling the data in this bulletin was intrusted to Mr. R. S. Langdell, my assistant, who has for the past three vears been devoting his energies to carrying on the nursery work at Amherst, and furthering the reforestation work throughout the State.

F. W. RANE,

State Forester.

Boston, MIAss., March 1, 1910. 



\section{REFORESTATION IN MASSACHUSETTS.}

\section{THE FOREST NURSERY.}

One of the first things in nursery work is the procuring of the seed. In most cases our native trees furnish this in great abundance, though in some years the seed crop is much more heavy than in others, due to climatic conditions. Practically all of the seeds referred to may be easily gathered in almost any locality throughout the State.

\section{Procuring the Seed.}

The white pine (Pinus strobus), our native pine, bears its seed in the cones or burrs, which generally grow in clusters of twos or threes on the upper branches of the tree. Many persons wonder why it is that they cannot find the seed in the opened cones picked up in any pine grove; in fact, a number of cases have been known where persons have planted the cones which have fallen to the ground in late fall or winter, the seales open and the seed eseaped, and expected to obtain a crop of trees. The seed is located two under each scale of the cone, and is about the size of a raisin seed, being provided with a small, bee-like wing, which favors its distribution by the wind. The cones commence to turn brown in this section about the middle of August, and from then on ripen very rapidly, one or two sunny days drying the scales so that they open and set the seeds at liberty. The cones must therefore be picked while green, before the scales have opened, by climbing the tree and picking by hand or with pruning shears. Sometimes a person may be fortunate enough to find a large number where the trees are being out for lumber, - they are then readily picked into baskets. The squirrels also at times cut off large numbers of cones, which fall to the ground and can be gathered up, care 
being taken to select cones which have matured sufficiently for the seeds to be fertile.

After the cones are picked they should be spread out in the sun on a smooth floor (Fig. 1), where they can be raked over from time to time, to aid drying. In a week or two the scales will begin to open and the seed fall out. The cones can then be raked off and the seed swept up. If the cones are then put into a bag and flayed, any remaining seed will rattle out. The cones should be kept from getting wet while drying, as the scales will close and will have to dry thoroughly again before opening. They should also be kept away from birds and mice, which often destroy large quantities of seed before being detected. If a large amount of seed is to be extracted, a drying room with drying racks and screens may be provided. ${ }^{1}$

Spruce, hemlock, larch, Norway pine, pitch pine and other coniferous tree seeds can be gathered and extracted in the abore manner. If properly stored, the seed in most cases retains its vitality for a number of years.

The seed should be cleaned by winnowing, and then put into bags and kept in a cool, dry place through the winter, to be in readiness for planting the following spring.

The seed of maple, ash and other deciduous trees, except the nut trees, is most readily picked from the tree. The oak, chestnut, hickories, locust and some others ripen their seed in the fall, and shed it to the ground by the action of frost and wind.

\section{Layering Seed in Sand.}

It is best in most cases to protect the germinating qualities of nut seeds during the winter by storing in sand.

Layering is a method of storing certain seeds through the winter, and should be resorted to when keeping chestnut, oak, hickories, etc. For this purpose a well-drained slope should be selected, and a hole dug in the ground large enough to hold the seed; a layer of sand about 3 inches deep should then be placed in the bottom, then a layer of seed, followed by a layer of sand, and so on till the seed is stored. It should then be corered about 1 foot deep, to protect it from freezing and thawing. When only

' Bulletin No. 73, Forest Service, Washington, D. C. 


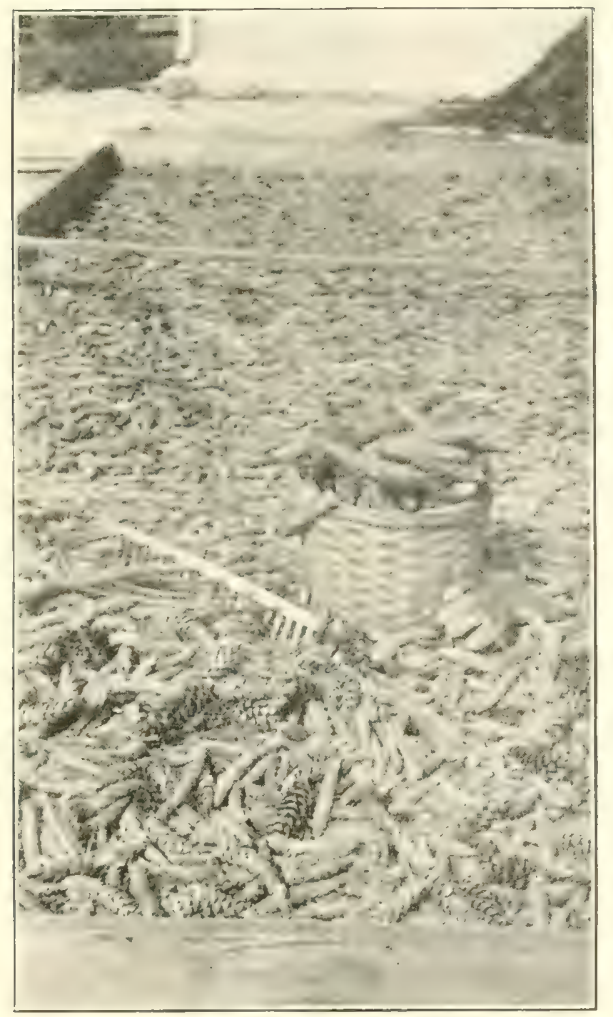

FIG. 1.-Pine cones spread out to dry, in order that seed may be extracted. 

a small amount of seed is to be stored, a large drain pipe set in the ground with the bottom covered with fine mesh wire is rery convenient, the seed being layered inside the pipe, to protect it from rodents. A wooden box used instead of the drain pipe will answer the purpose very well, and make it easier to remove the seed in the spring.

\section{Site for a Nursery.}

$\Lambda$ level, well-drained site should be selected for a nursery, the soil being preferably a sandy loam, not subject to washing and free from stones. It is also well to select a plot near the house, where it will be convenient to take care of, and ofter some protection from birds and rodents, which often destroy the sced after it has been planted. A small plot in the garden will be well suited for the purpose.

\section{Preparation for the Seed Beds.}

The land to be used for the seed beds should first be well plowed and harrowed till the soil is pulverized. A small amount of well-rotted barn-yard manure, free from weed seeds, may be used to adrantage. The beds should then be laid ont, the most convenient size being a bed 4 feet wide and any convenient length, with walks 2 feet wide between the berls. If the surface soil retains water it will be well to raise the bed a few inches above the walk, and have it about 1 inch higher in the center than on the sides. This will give the moisture a chance to drain off. After the beds have been made up they should be raked orel with an iron rake till all small stones and lumps have been removed and the soil thoroughly pulverized. The bedis are then ready for the seed, which may be planted in drills or sown broadcast.

\section{Time to plant Seed.}

As a rule, the seed should be planted in the spring, as soon as the ground has warmed up a little, it being generally arlvisable to plant the seed in drills, to facilitate cultivating the seellings. If planted broadcast, the seedling growing near the middle of the bed will be limited for light and space. 


\section{A Marker.}

For making the drills to plant pine seed, a marker made of strips of wood 4 feet long, nailed to cross-pieces on a board, with the strips about 4 inches apart, and so arranged as to make a drill about $1 / 2$ inch deep, has been found rery useful. The marker (Fig. 2) can then be pressed down across the bed. If, each time it is mored, the inside cleat is allowed to rest in the trench previously made by the outside eleat, very uniform drills can be made.

\section{Sowing the Seed.}

After the drills have been made, the seed should be sown similarly to any garden seed. In case of pine seed, if sown nearly touching each other, 1 pound would cover a bed 4 feet wide and 40 feet long. After the seed is sown, it should be covered by lightly brushing or sifting a little fine soil over it and firming it slightly. If the marker has been made by nailing strips to a smooth board, the back side can be used for this purpose. Some nurserymen advise making a box bed similar to a hot bed, but with holes in the side to act as rentilators and for drainage, a wire screen protecting the beds from rodents.

\section{Miulching.}

As soon as the seed is sown, the beds should be corered over with leares or needles about 3 inches deep, in order to hold the moisture in the ground and keep an even temperature. This prevents the soil from becoming dry, in which case the seed would not germinate. As soon as the seed commences to appear above ground, the mulch should be carefully removed. Screens for shading should be provided in the mean time, as pine seed does not generally germinate for from two to three weeks.

\section{Shading.}

For the first two years most coniferous seedlings need to be protected from the sun (Figs. 5 and 6 ). For this purpose both screens (Fig. 3) may be cheaply made, using two laths as crosspieces, and nailing others to them about their width apart. If a lath is nailed on slanting thromgh the middle, it makes the screen 


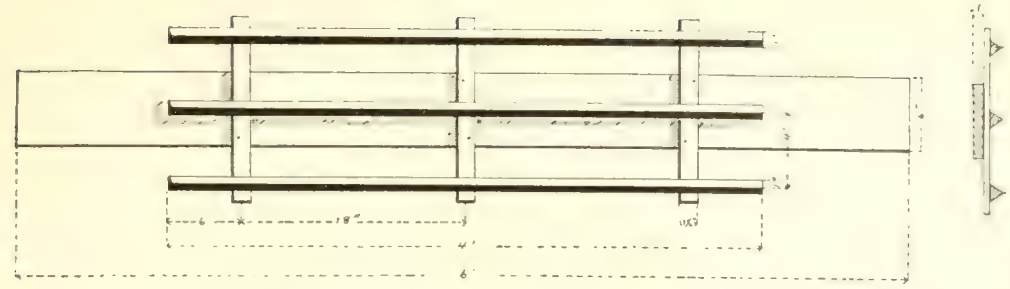

FIG. 2. - View of marker for making drill in which to sow evergreen seeds.

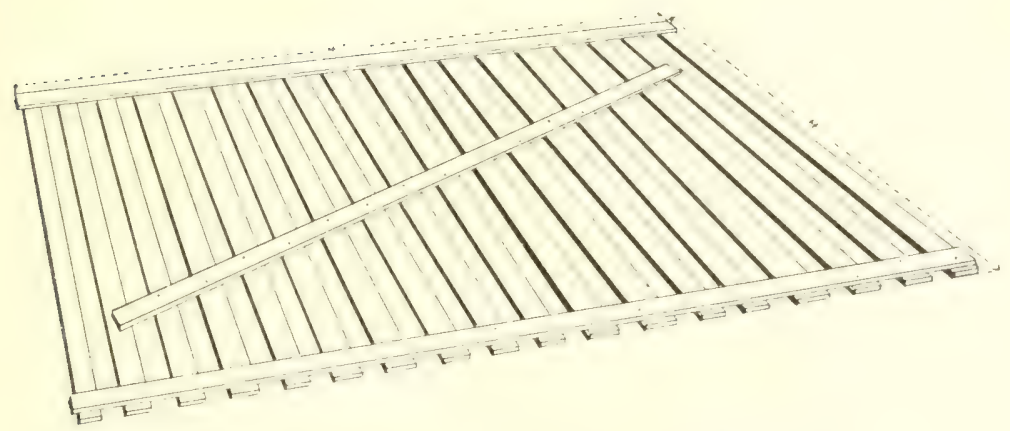

FIG. 3.- View of lath sereen to be used in shathe evergreen seedlings from the sun

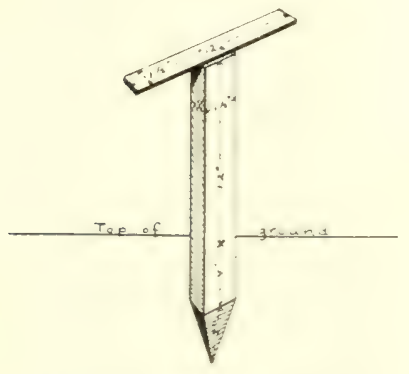

FIf. 4. - Stake to be drisen into ground to hold screens athore the seed berls. 

much more tirm. The screens should then be placed alonut 1 foot abore the bed, the laths ruming north and south. Stakes with a cross-piece 1 foot long nailed on top (Fig. 4), stuck into the ground at each corner of the screens, will hold them in place.

\section{Damping off.}

After the seedlings have appeared above ground and the mulch been removed, a dangerous disease to the seedlings is liable to appear, especially if cool, wet weather sets in. This disease causes the seedlings to wilt or die off in large numbers, the stem near the ground rotting off, so that the seedling tips orer and dies. The best way to prevent this disease is to remove the screens for a short time each day. Care must, however, be taken not to allow them to remain off long enough for the sun to burn the seedlings, as they are very tender at this stage. If the beds are sprinkled with coarse sand, it also prevents the soil from becoming wet and damp.

The seed beds should be carefully weeded as soon as any weeds appear, care being taken not to root up the seedlings. After the seedlings have obtained a good start, the roots have branched out and a firm hold has been secured, a small hand weeder may be drawn between the drills, to remove the small weeds and at the same time cultivate and fine the soil about the roots of the trees.

Oak, chestnut and other deciduous tree seeds may be sown in beds 8 or 10 feet wide and 25 to 50 feet long, the seed being planted about 2 inches apart in trenches 1 foot apart. This leaves ample space for cultivating seedlings. It is a safe rule to plant seed twice its own depth, as if planted too deep it is liable not to come up till the following spring. Under average conditions, deciduous seeds need not be mulched or shaded. In a short time they should be of sufficient size so that a small hand cultivator may be used.

\section{Protection in the winter.}

In order to protect the tender seedlings from alternate freezing and thawing during the winter, they should be mulched with leaves, pine needles or straw. The screens should then be removed from the seed beds of evergreens, and the mulch spread over the beds to a depth of from 3 to 4 inches. The screens can 
then be laid down on the mulch, to hold it in place and prevent it from being scattered by the wind.

The seedlings of decidnous trees need not be mulched, but it is often well to hill them up, slightly just before the ground freezes, by piling a littie earth up around the stem with a hoe or cultivator. Mulching may, however, be resorted to where the winter is severe.

In the spring, as soon as the snow is off and the frost out of the ground, the mulch should be removed and the screens put up orer the everereen seedlings. Ireding should he done when necessary during the season, from three to four times probably being sufficient if they have been well taken care of in the previous year.

\section{Hardening off of Evergreens.}

In the later part of the season, when the sum is not as strong as during the summer, the screens should be removed for a short time each day, a little longer each time, and finally left off altowether. This will harden the plants. and get them into (ondition to withstand the second winter without mulehing, so that they will be ready to transplant in the following spring.

\section{Transplanting.}

When the white pine seedlings are two years old, they should be either transplanted in the nursery (Figs. 7 and 8) or set in their permanent sites. It is generally preferable to transplant them in the mursery for one or two years, in order to form a more compact root growth and make a more stocky plant. In the spring, as soon as the frost is well out of the ground (April or May), the seedlings should be dug up and tied in bunches of 50 or 100. In digging, eare should be taken not to break off many of the small rootlets. It is also better to choose a cloudy day for the work, rather than a bright, sunshiny day, when there is danger of the roots drying out quickly.

\section{Puddling.}

As soon as the trees are dug and tied into bunches, the roots should be dipped into a puddle of mud and water, mixed to the consistency of common paint. This covers the roots with a thin coating of dirt, which prevents their coming in contact with the air and drying out. 


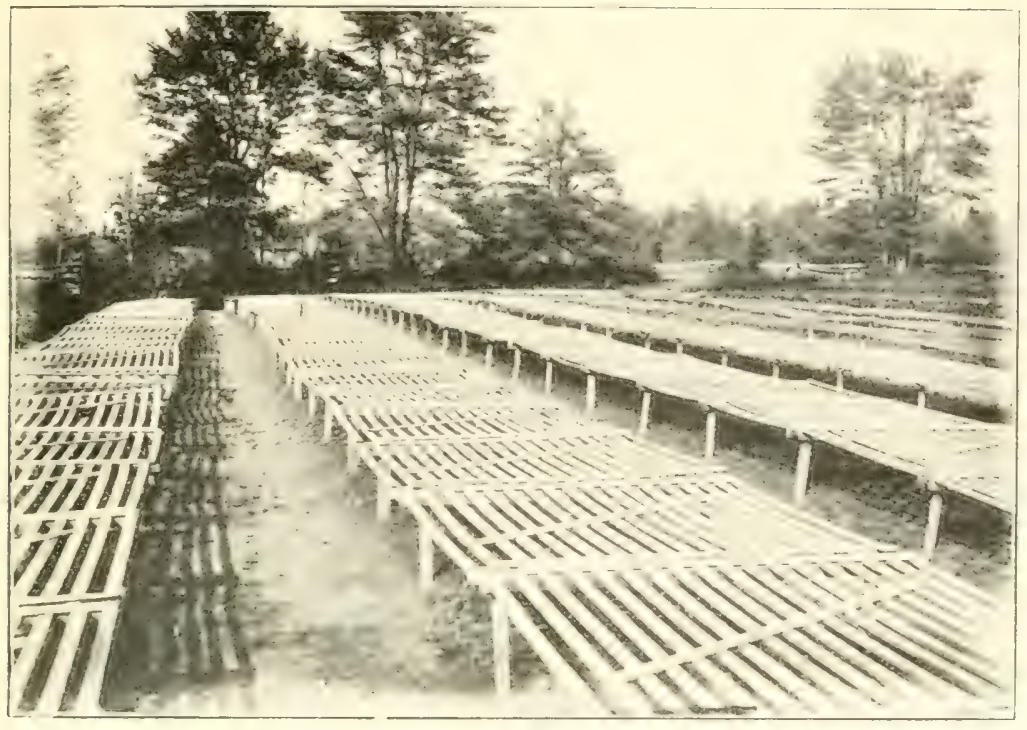

Fra. 5.- Showing methot of sereening erergreen seedlings from the sun during the first year.

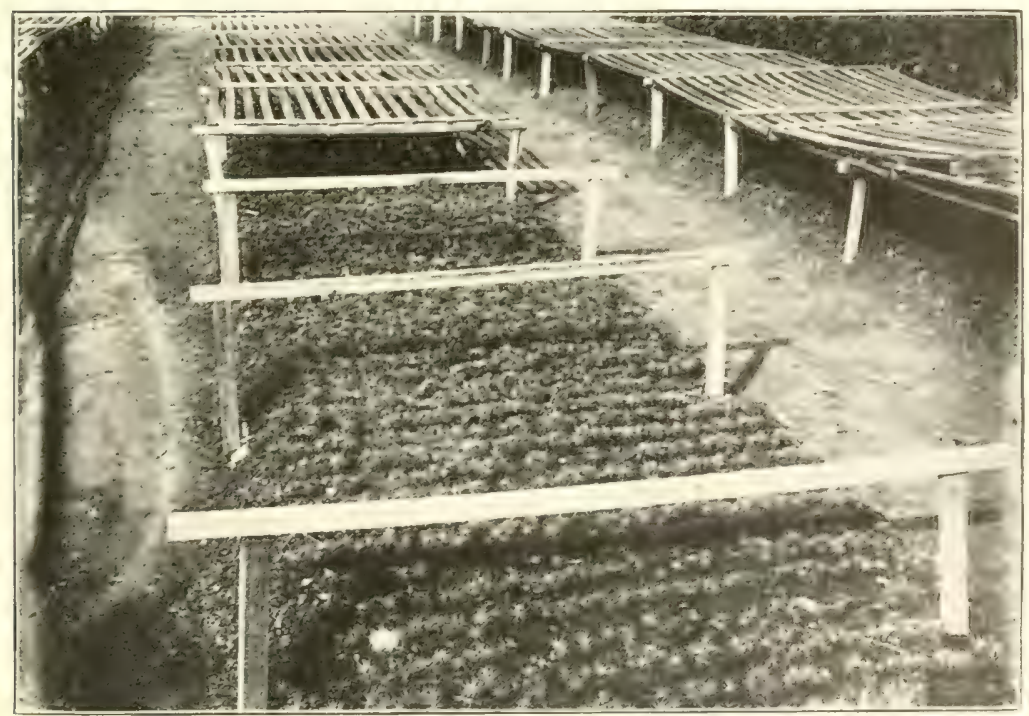

Fir. fi. - View of the seed beds with screens removed, to allow the beds to dry out and prevent damping off, 



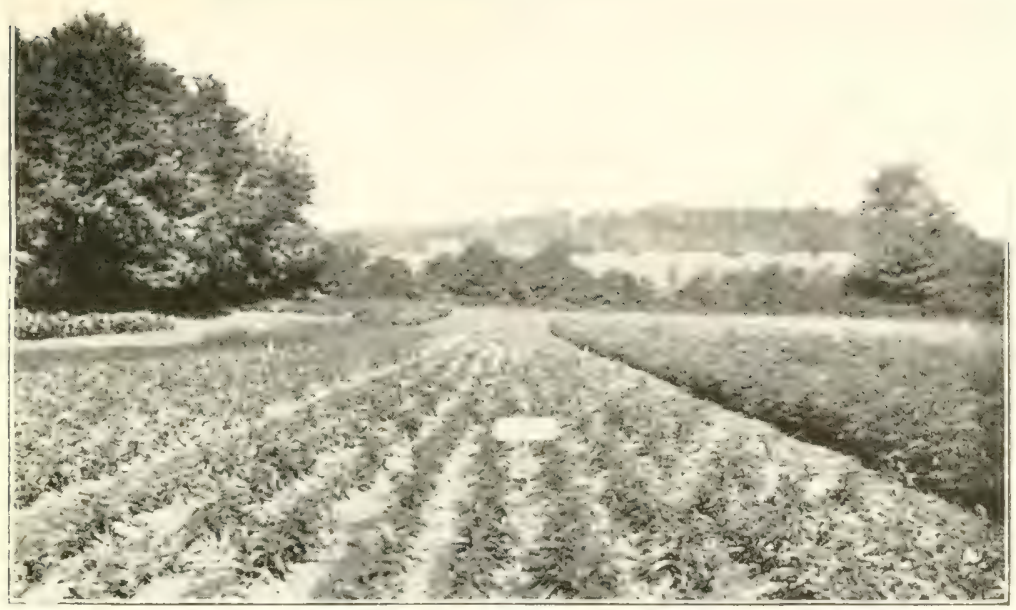

FIG. 7. - View of transplant beds, seedlings being set in rows ahout a foot apart, to aid in cultivating.

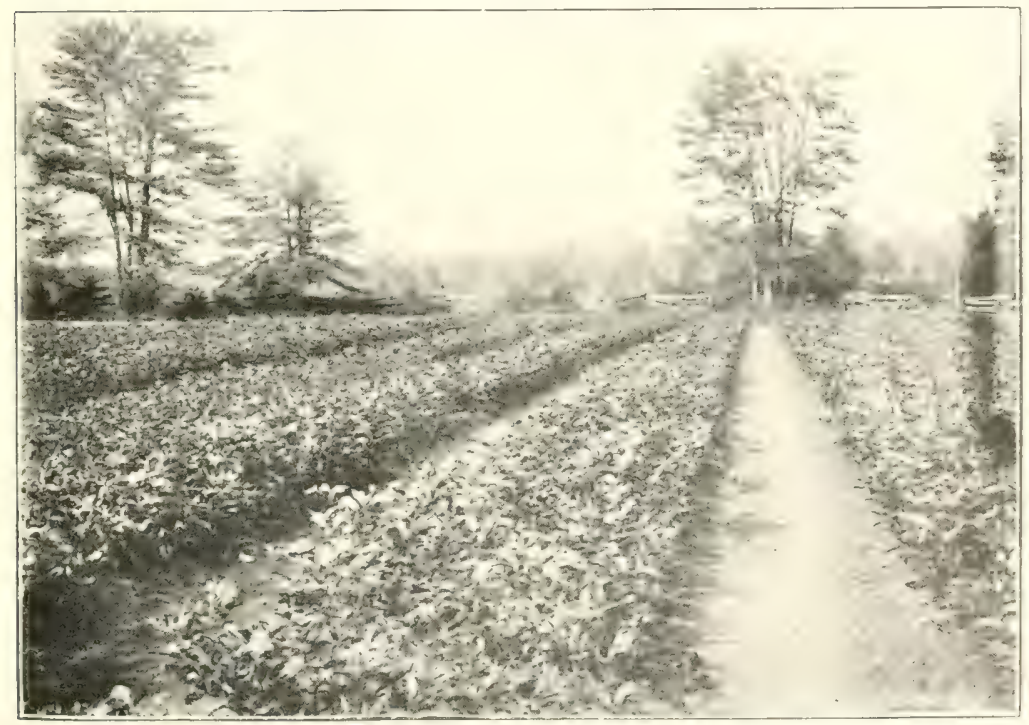

Fig. S. - White ash transplants, two years old, ready to set in permanent aite. 



\section{Heeling in Young Trees.}

To keep the trees in good condition till ready for transplanting, they may be temporarily set in a trench about 1 foot deep, dug with one side on a slant. The bunches of seedlings may then be placed side by side against the slanting trench, and a little damp soil thrown over the roots and firmed down.

Most hardwood trees should be transplanted when one year old, as they develop a long tap root, which, if allowed to grow for a number of years without resetting, becomes so well rooted that it will be impossible to dig up the plant without serious injury.

\section{Root Pruning.}

In order to cause the tree to develop a compact root growth, it is generally considered advisable to cut off a portion of the tap root on deciduous seedlings, such as ash, hickories, catalpa, etc. The cutting off of about one-third of the root causes it to develop a lateral growth.

\section{Packing Seedlings.}

When the trees are to be removed to some distance from the nur'sery, the bunches should be packed in boxes, with the roots in damp sphagnum moss. A layer of damp moss should be put in the bottom of the box, and by alternating the bunches so that the roots will all be in the center, making first a layer of moss, then a layer of trees, and so on till the box is full, a large number may be packed in a small space. It is also well to puddle the roots before packing, giving them an additional coating of soil. 


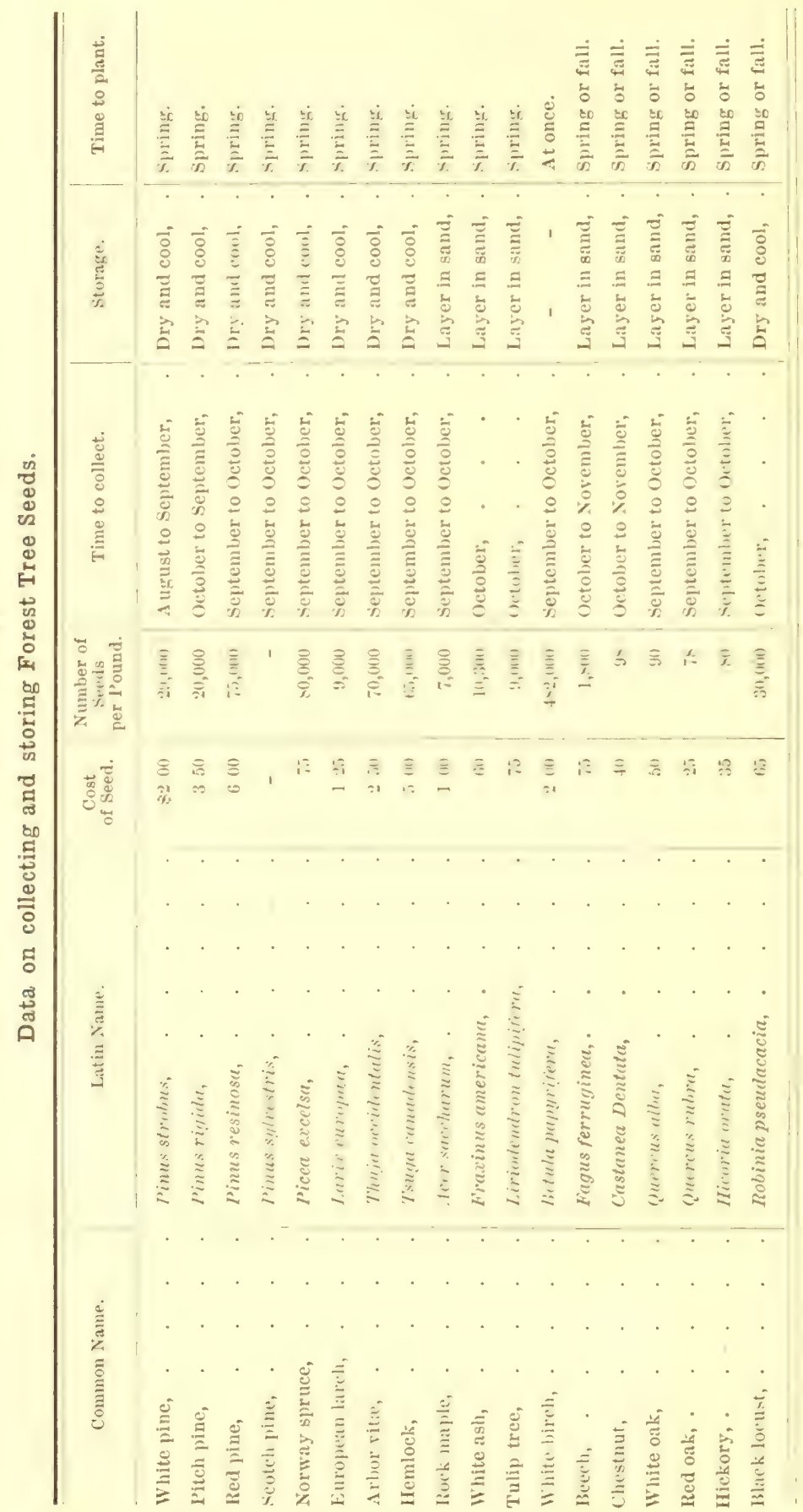


Cost of Seedlings and Transplants per Thousand.

\begin{tabular}{|c|c|c|c|c|c|c|c|c|}
\hline \multirow{2}{*}{\multicolumn{2}{|c|}{ VARIETY. }} & & \multicolumn{3}{|c|}{ Price of American Trees. } & \multicolumn{3}{|c|}{$\begin{array}{l}\text { Price of ForeigN } \\
\text { TraNSPLANTS.1 }\end{array}$} \\
\hline & & & 1 Year. & 2 Years. & 3 Years. & 2 Years. & 3 Years. & 4 Years. \\
\hline $\begin{array}{l}\text { White pine, } \\
\text { Pitch pine, } \\
\text { Red pine, } \\
\text { Scotch pine, } \\
\text { Norway spru } \\
\text { European lar } \\
\text { Arbor vita, } \\
\text { Ifemlock, } \\
\text { Rock maple, } \\
\text { White ash, } \\
\text { Tulip tree, } \\
\text { White birch, } \\
\text { Beech, } \\
\text { Chestnut, } \\
\text { White oak, } \\
\text { Red oak, } \\
\text { Hickory, } \\
\text { Black locust, }\end{array}$ & $\begin{array}{l}: \\
: \\
\text { ce, } \\
\text { ch, } \\
: \\
: \\
: \\
: \\
:\end{array}$ & " & $\begin{array}{c}\bar{z} \\
\bar{z} \\
- \\
\overline{-} \\
\bar{z} \\
\overline{-} \\
8500-8800 \\
600-800 \\
- \\
600 \\
900 \\
800-1500 \\
1000-1500 \\
700-800 \\
800-1000 \\
350-500\end{array}$ & $\begin{array}{ccc}\$ 3 & 00-\$ 5 & 00 \\
4 & 50-7 & 00 \\
15 & 00 & \\
4 & 00-6 & 00 \\
6 & 00 & \\
6 & 00-8 & 00 \\
5 & 00 & \\
16 & 00 & \\
12 & 00-16 & 00 \\
10 & 00-15 & 00 \\
& - & \\
14 & 00-35 & 00 \\
& - & \\
20 & 00-35 & 00 \\
& - & \\
10 & 00-12 & 00 \\
12 & 00-15 & 00 \\
8 & 00-15 & 00\end{array}$ & 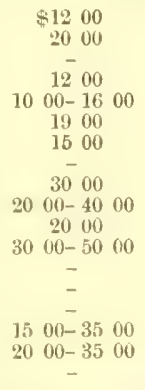 & 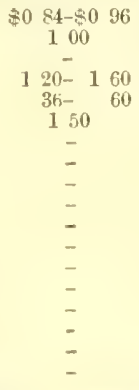 & $\begin{array}{l}\$ 264 \\
300 \\
- \\
180 \\
144 \\
200 \\
- \\
- \\
- \\
= \\
= \\
= \\
- \\
- \\
= \\
- \\
- \\
-\end{array}$ & $\begin{array}{l}\$ 288 \\
- \\
- \\
288 \\
240 \\
- \\
= \\
- \\
- \\
- \\
- \\
= \\
- \\
- \\
- \\
- \\
-\end{array}$ \\
\hline
\end{tabular}

1 Freight and charges on imported stock average from $\$ 0.50$ to $\$ 0.75$ per thousand.

\section{REFORESTATION.}

The total area of Massachusetts is about 5,321,787 acres, of which 2,672,950 acres is land adapted only to the growing of trees. Of this area there are about 700,000 acres which at the present time constitute practically worthlese tracts, leing simply a tax to the owners, who at a very small outlay could bring the land back into a profitable forest growth, as well as adding to the scenic beauty of the section.

This land lies in tracts varying in size from one to thousands of acres. Practically every farm has a portion which at one time or another has been cut off, burnt over, or allowed to relapse into a condition where it is no longer a source of revenue, but a piece of property which brings in no return, though it is still taxable. Lumbermen, mill owners, water-right companies and farmers all have some land which falls under one of the following types, and it is this sort of land which fortunately furnishes ideal conditions for forest planting.

\section{Cut-over Land (Fig. 9).}

It can be safely said that every lumberman owns one or more tracts of land which he has cut off, but which has not come back into a growth which will ever be of any great profit to himself 
or others, if allowed to remain in its present condition. Nature intends that this land should remain in forest growth, but through inconsiderate cutting it has come up to an undergrowth of small value. It is always preferable to restock this type of land as soon as possible after it has been cut, as the sprout and hardwood growths, if allowed to gain too great a headway, will hold the seedlings in check.

\section{Burnt-over Land (Fig. 10).}

()n land which has been suljected to repeated fires, destroying the growth and ground corer, the soil is left free to the action of the weather, to be quickly dried out by the sun, or, if on a side hill, to be washed into the valley by rains. The seed or seedlings which may have been on the ground have been destroyed, and the land nirght lie for a long period of years before it womld reseed itself naturally. Land of this trpe, therefore, should be set with considerable care, in order to obtain the best results. It is generally arlisable to set a three-your-old or four-year-old transplant here, rather than seedlings.

\section{Run-out Pasture Land (Figs. 11 and 12).}

Ifany of the farms throughout the State are becoming run out, and are allowed to grow up to hrush and modesirable hardwoods. Pasture lands exprecially are being encroached upon by some of our less valuable trees, such as bird cherry and gray hireh, which so overshade the gromend that good pasturage runs out, and the lot is abandomed for fields affording better forage. In many cases scattering white pine hare crept in, and probably in time would seed in the whole piece: but the old trees, while doing gond work in reseeding. would he of little value, as, growing so seattered, they would levelop large lateral branches, instead of giving a clear, straight bole to the trunk, so desirable in the best grade of lumber. If the lot could be set out with seedlings and the trees allowed to grow in sufficiently dense stands, the lower branches would die off naturally, and smonth, elear lumber would be assured. 


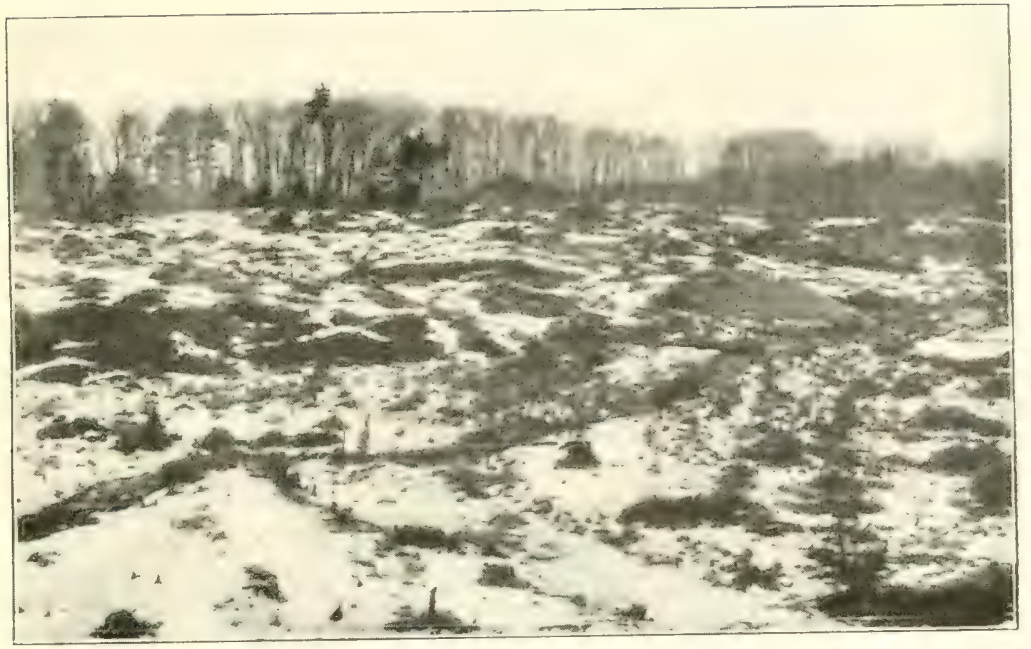

FIG. 9.-Cut-over land, suitable for restocking with white pine. The sawdust pile tells the story.

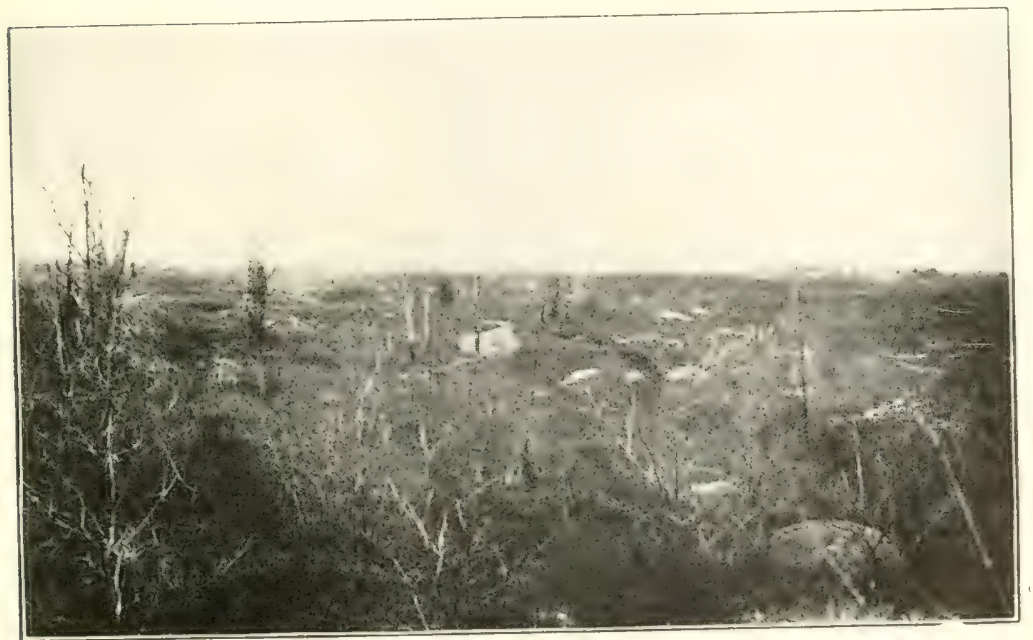

FIg. 10. - Burnt-over land, where all the seed and young trees have been destroyed by repeated fires. Land should be reforested. 



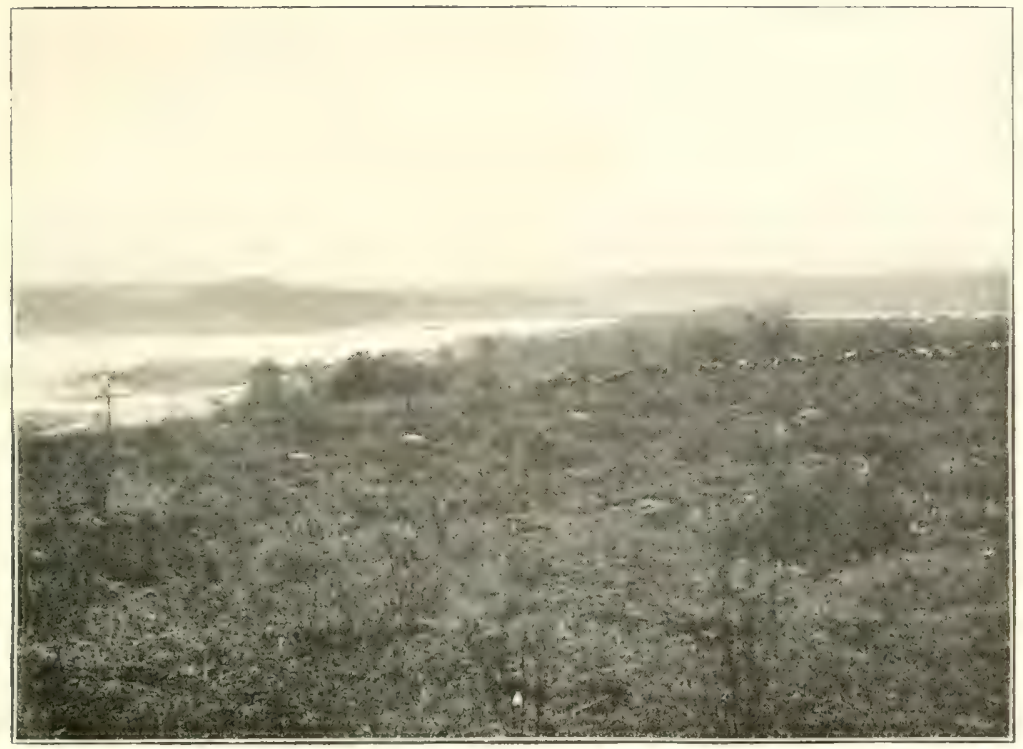

FIG. 11. - Run.out pasture land, which should be brought back into forest growth.

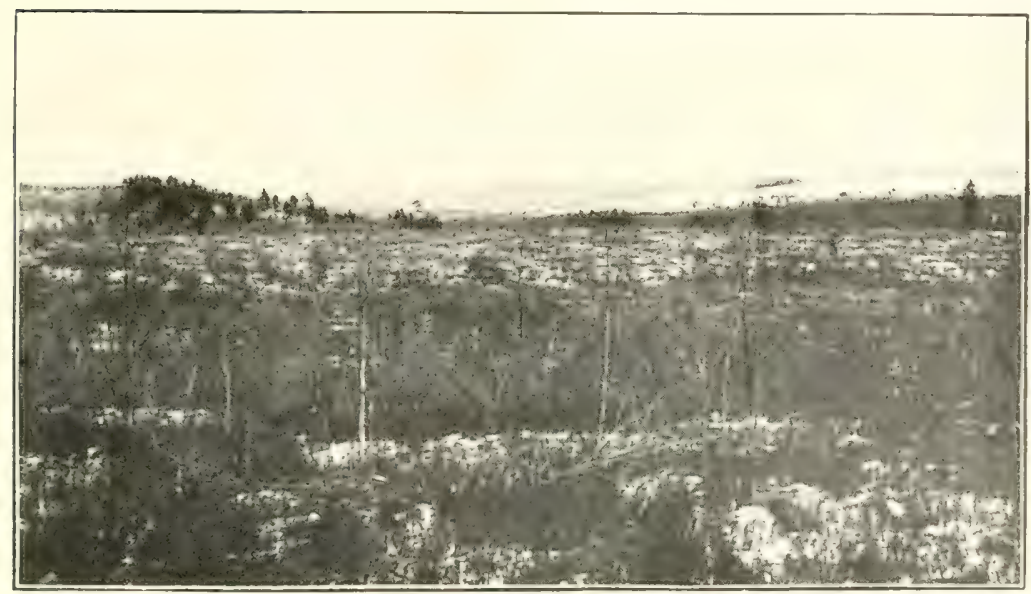

Frg. 12, - Land coming un to gray birch and undesirable hardwood, and which should be reforested. 



\section{Seedlings and Transplants.}

It is generally considered advisable to set tramsplants rather than seedlings, although under most conditions in this section the two-year-old white pine has been planted with good results. As a rule two-year-old seedlings may be planted on land classed as run-out pasture land or on cut-over land with good success, there being a little shade afforded by gray birch or low bushes.

Three-year-old or four-year-old transplants are adapted for planting on open land, exposed to the drying effects of sum and wind (Fig. 13). As their root growth is large, they can be more deeply set in the ground where they can take up the moisture; whereas, if the roots were near the surface, as they would necessarily be if seedlings were used, the trees would die from lack of moisture in the top soil. It is also best to set transplants in old fields or mowings, where small plants would be beaten down and choked out by the thick fog or dead grass.

\section{Varieties to plant}

There are a number of varieties of trees which may be planted with good results. It is advisable to set some tree which grows naturally in the locality in which the work is to be done.

The white pine (Pinus strobus) (Fig. 14) has been used largely for reforestation purposes throughout the State, and has adapted itself to most of our New England conditions; in fact, this section of the country at one time was covered with primeval forest comprised largely of white pine. The rapidity of its growth and the many uses to which the variety of wood may be put makes it a practical tree for forest planting, and the one most used in this work. It is, however, recommended to use some other variety on Cape Cod, mless the plantation is well protected from the wind, which on the Cape causes a somewhat stunted growth.

The white ash (Fraximus americana) is well suited for planting on a springy side hill, where the growth and texture of the wood of this variety often reaches its highest quality. It is also practically immune from the attack of the gypsy and brown-tail moths, which are so detrimental to the trees in many towns in the eastern part of the State. 
The Norway spruce (Picea excelsa), a tree grown on an extensive scale in European countries with climatic conditions similar to our own, is a tree well suited for planting in sections where our native red spruce is the predominating species. It is a rapid grower, and its wood is also claimed to have properties for the manufacture of paper pulp not contained in other native trees. This variety has been planted quite extensively in New York State, where excellent results have been obtained.

For planting on Cape Cod, the Scoteh pine, pitch pine, Austrian pine, black locust and oak should be used. The Cape conditions vary in a number of ways, and should be looked into to some extent before undertaking to plant the trees. In many sections of the Cape repeated fires have so destroyed the ground cover and eren burnt into the top soil that a transplant should be used, whose root could reach down into the soil deep enough to obtain moisture. In other cases a screen of some rapidgrowing trees should be planted around the plantation, to act as a protection from the prevailing wind, which often causes the trees to lean. In almost every instance a plantation on the Cape should have some protection from forest fires. The sandy formation of the soil ofters great inducement for making and retaining a fire line, at rery small expense. A furrow in most cases could thus be made with a plow, and the dry, sandy soil thus turned up would act as a check to a ruming fire. It conld be very easily kept free and clear from dead grass, leaves and brush. In fact, if the torns comprising the Cape could be brought to see the advantage of maintaining a strip 50 feet wide on each side of a town line, many of the large disastrous fires of that section could be prevented. And, as the town lines necessarily have to be blazed or marked every few years, the labor and expense for such work conld be done away with. This is a line of work which might receive some attention in other sections of the State, as well as on the Cape. In a number of towns where a rather modified form of the work has been done, it has been found remarkably effective and the expense comparatively small. 


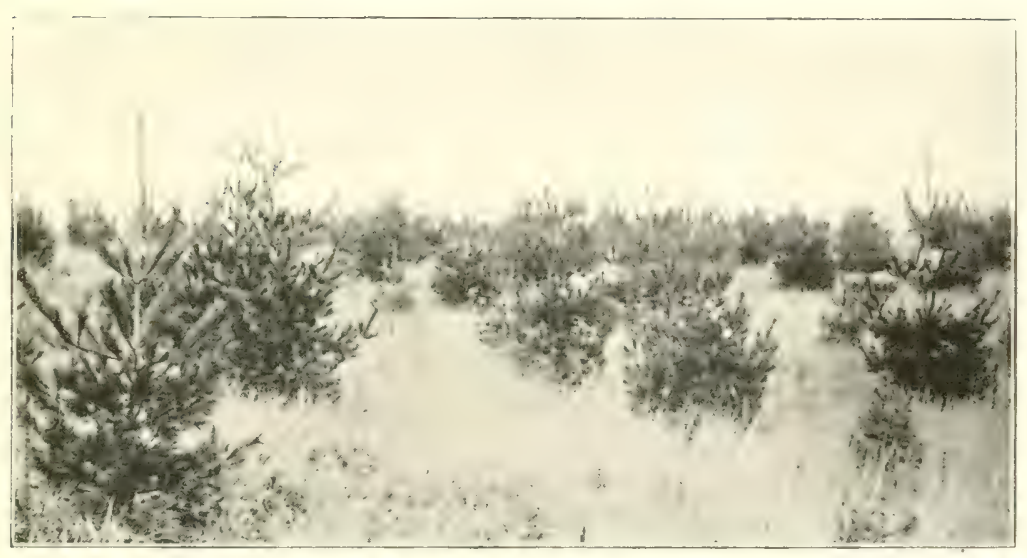

FIG. 13. - Land planted with white pive transplants, six years after setting. Notice remarkable growth of leading shoot. 



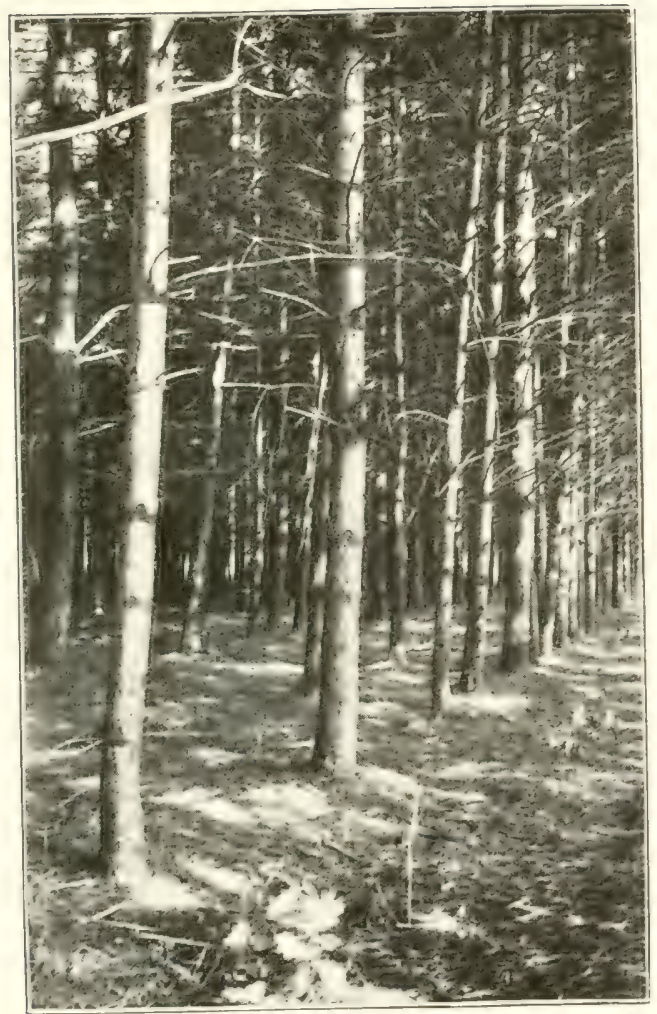

FIG, 14-View of thirty-eight-year-old planta. tion of white pine, showing how the lower branches have died from lack of light, giving a clear, straight bole to the trunk, and produc. ing clean lumber, free from large knots. 

Trees suitable for Forest Planting in Massachusetts.

\begin{tabular}{|c|c|c|c|c|c|c|c|}
\hline NAME 0 & oF & SPECIES & & & Soil. & & Uses. \\
\hline $\begin{array}{l}\text { White pine, } \\
\text { Pitch pine, } \\
\text { Red pine, } \\
\text { Norway spruc } \\
\text { Europein larc } \\
\text { Arbor vitie, } \\
\text { Hemlock, } \\
\text { Rock maple, } \\
\text { White ash, } \\
\text { Tulip tree, } \\
\text { White birch, } \\
\text { Poplar, } \\
\text { Beech, } \\
\text { Chestnut, } \\
\text { White oak, } \\
\text { Red oak, } \\
\text { Iickory, } \\
\text { Black locust, }\end{array}$ & 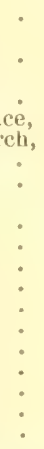 & $\begin{array}{l}: \\
: \\
: \\
: \\
: \\
: \\
: \\
: \\
:\end{array}$ & $\begin{array}{l}\dot{ } \\
\dot{ } \\
\dot{ } \\
\dot{ }\end{array}$ & $\begin{array}{l}\dot{ } \\
\dot{ } \\
\dot{ } \\
\dot{ }\end{array}$ & $\begin{array}{l}\text { Any soil not near coast } \\
\text { swampy, } \\
\text { Sandy soll, on coast, } \\
\text { Sandy soil, inland, } \\
\text { Sandy loam, } \\
\text { Light soil, } \\
\text { Sandy soil, } \\
\text { Well-drained soil, } \\
\text { swampy, } \\
\text { Well-drained soil, } \\
\text { Wet land, swampy, } \\
\text { Sandy loam, } \\
\text { Sandy or gravelly soil, } \\
\text { saudy or gratrelly suil, } \\
\text { Moist loam, } \\
\text { Well-drained soil, } \\
\text { Sandy loam, } \\
\text { W ell-drained soil, } \\
\text { Sanly loam, } \\
\text { Sandy soil, on coast, }\end{array}$ & $\begin{array}{r}\text { tor } \\
\vdots \\
\vdots \\
\text { or } \\
\vdots \\
\vdots \\
\vdots \\
\vdots \\
\vdots \\
\vdots\end{array}$ & $\begin{array}{l}\text { Lumber, box boards. } \\
\text { Lumber, to hold sand in } \\
\text { check. } \\
\text { Lumber, ship timbers. } \\
\text { Lumber, Chriptmas trees. } \\
\text { Piles, ship building. } \\
\text { Posts, shingles, etc. } \\
\text { Lumber, ties, tanning. } \\
\text { Furniture, floors. } \\
\text { Lumber, carriages, tools. } \\
\text { Lumber, pulp wood. } \\
\text { Furniture, fuel, handles. } \\
\text { Pulp wuet, excelsat. } \\
\text { Tools, laths, etc. } \\
\text { Poles, posts, tics, etc. } \\
\text { Agriculturial tools. } \\
\text { Lumber, fuel. } \\
\text { Carriage building, tools. } \\
\text { Posts, ties, etc. }\end{array}$ \\
\hline
\end{tabular}

\section{Nurserymen.}

Auerican Nurenguen.

Northeastern Forestry Company,

American Forestry Company,

D. Hill,

Evergreen Nursery Company, Garfield Williamson,

Massachusetts State Forester,
New IIaven, Conn.

South Framingham, Mass.

Dundee, Ill.

Sturgeon Bay, Wis.

52 Broadway, New York, N.Y. Boston. Mass. ${ }^{1}$

\section{FOREIGN NuRSERMEN.}

\section{J. Heins Solne,}

Julius Hansen,

Pierre Sebire \& Son,

Dickson Nurseries,

Peter Schott,
Holstenbeck, Ger.

P'inneberg, Gier.

Ussy, Calvados, France.

Chester, Eng.

Knittelshem, Rheinpfalz, Ger.

\section{Spacing of Trees.}

In order to produce a dense stand of trees, where the lower branches will die off and fall to the gromel from lack of light, giving a clear, straight bole (Fig. 14), so desirable for lumber purposes, the trees should be set 6 feet apart each way, or about 1,210 to the acre. The exact number will necessarily vary according to the condition of the land. On rough, stony tracts,

1 The State Forester often knows of local growers that have from one thousand to tive hundred thousand trees for sale each year, and is glad to gire information in regard to them. 
where the trees will be set only where there is sufficient soil for the roots to obtain a firm footing, the number of trees may be a few hundred less than on land covered by a good top soil. If the trees are set in rows rumning from one side of the lot to the other, it will be found quite easy to keep track of the portion which has been set. The distance apart may be very readily determined by making the holes two paces apart, or about 6 feet. It is also generally considered best to make a clear planting, rather than to mix rarieties.

\section{Heeling in on Lot.}

Where a large number of trees are to be planted, they should be heeled in on the lot in a place where there is some protection from the sun; otherwise, a screen of brush may be put up. It will also be well to choose a spot near a brook or stream, as the seedlings will need to be watered if they become dry before transplanting. After they have been set in their permanent site they will take care of themselves, as to water them when spread out over a large area would be an almost impossible undertaking.

\section{Method of setting the Trees.}

The most convenient method of setting the trees is for the men to work in pairs, one making the holes and the other planting the trees. The first man with a grub hoe or mattock should strike into the ground (Figs. 15 and 16) and make a small hole, leaving as much as possible of the soil remored where it can be readily used to place around the roots when the tree is set; then he takes two paces and makes another hole. The second man, carrying a pail containing a bunch of seedlings, the roots of which are in a puddle of mud and water always to be kept in the pail, takes a plant and sets it in the hole (Fig. 17) at about the same depth as it originally grew, covering the roots with fine soil and firming it down by pressure of the foot (Fig. 18). The men should keep together and work from one side of the lot to the other and then back, the rows being kept about two paces apart. If stakes with flags are placed along the outside row and mored from time to time, it will be much easier to follow the row. One man should superintend from six to eight pairs of men. 



\section{Time to plant.}

Planting should be undertaken as soon as the frost is out of the ground in the spring, the month of April and first of Mray being preferable, in order that the young roots may get started before the dry season sets in. Spring planting is preferable to fall planting, as the roots having started will not be as likely to be heaved out by the frost; although under certain conditions fall planting is sometimes resorted to, as in a case where a piece of land is too wet to work in the spring, but becomes dry during the summer and fall.

Two men working in the above manner will set about an acre per day, the expense of reforesting a tract, therefore, ranging from $\$ 5$ to $\$ 10$ per acre, depending on the price of the trees used and the cost of labor, white pine seedlings generally selling for from $\$ 3$ to $\$ 5$ per 1,000 , and labor ranging from $\$ 1.50$ to $\$ 2$ per day. The above estimate is based on about 30 lots planted by the State Forestry department, the lots ranging in size from 20 to 200 acres. It was generally found that the average cost is much smaller on large lots than on small ones, the men becoming used to the lay of the land, and thus being able to work with greater speed.

\section{Protection of Plantation.}

After the lot has been planted, it needs practically no care unless a large proportion die cout, in which ease the blanks shomld be filled in with transplants. The lot should not be pastured, as many of the young trees would be trampled down. It is also well to put up posters prohibiting hunters and herry pickers, who often throngh carclessness start fires capable of great damage.

\section{Fire Iines (Fig. 19).}

Around large lots a fire line should be cut on the exposed side of the plantation. to protect them from forest fires creeping in from adjoining land. A strip 50 feet wide cleaned of brush has been found very effective, the brush being piled and burned when the snow is on the ground (Fig. 20). On the side nearest the plantation (Fig. 20) a trench of feet wide shomld be grublest up or plowed up, and kept free from weeds and dead leaves. In this way a fire working in from other land would be unable to 
jump across the trench, having nothing to feed on. A trench on the outside of the line would also be of advantage; but in case culy one trench is deemed advisable, it is better to have it on the inside of the fire line. A line so made will offer a place for checking a fire or back-firing. The cost will vary according to the growth which has to be cleared. In cases where the wood is large enough to put it into cord wood, the expense will be small,

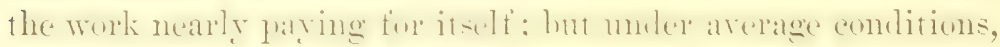
where no return can be derived, the cost will rary from $\$ 150$ to $\$ 200$ per mile. It is best to eut and pile the brush for such a line in early fall, when there will be no danger from sparks or fire runuing. A strip of this kind is of especial advantage along: railroads.

In extremely dry times, when there is danger from berry picker's or hunters, a look-out from some high knoll will be of adrantage. A fire patrol of a lot, whether planted, or a natural stand, is practical in dry times. The old saying, that "An ounce of prevention is worth a pound of cure," certainly applies in cases where forest fires are concerned.

\section{REFORESTATION WORK DONE BY THE STATE.}

Under "An Act to proricle for the purchase of forest land and for reforestation," passed by the Legislature of $190 \mathrm{~s}$, provision is made that private land ormers may turn tracts of land suitable for reforestation purposes orer to the State, to be planted and handled under practical forestry management, such orrners reserring the right to redeem the land at ans time within ten years, for the actual amount expended.

During the rear 1909 about 1,000 acres were deeded to the State and planted under the superrision of expert forester's from the State Forester's office, the work being done by local gangs (Fig. 21) picked up in the rarious torns where the lots were situated. The cost of planting, including price of trees and labor of setting, ranged from $\$ 5$ to $\$ 10$ per acre, according to land and labor conditions. A large proportion of the trees used in the work were purchased from outside nurservmen; but in the future, by raising the stock in State nurseries, the abore cost of planting should be reduced. 


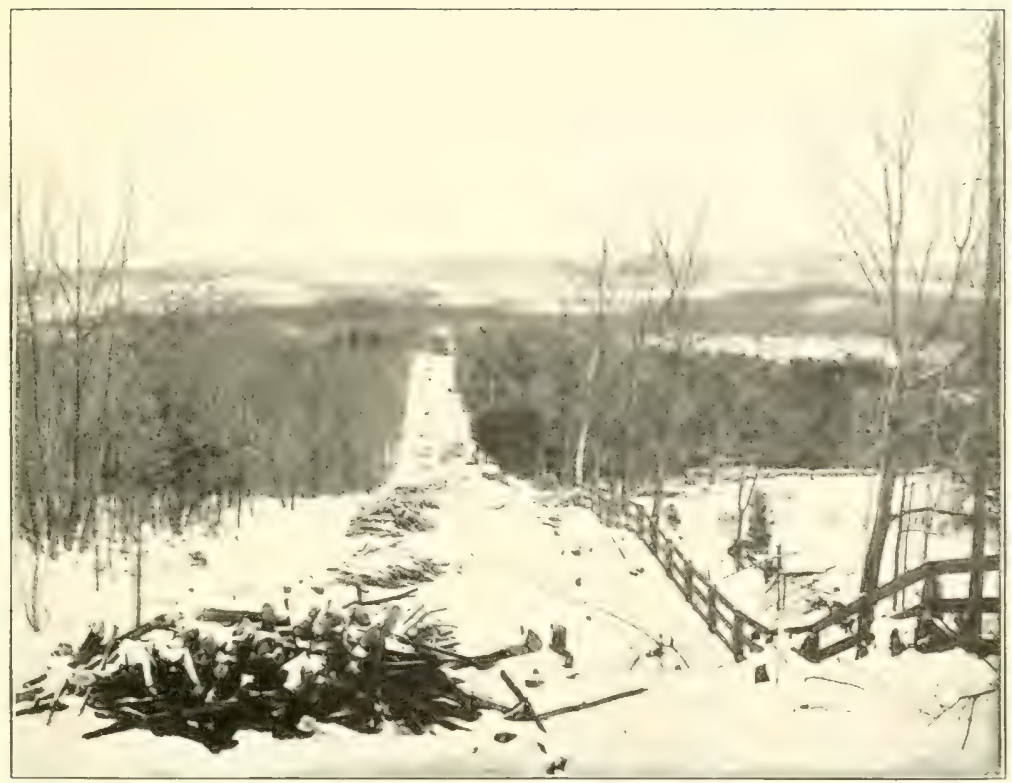

F1G. 19. - Fire line, Metropolitan Water Board reservation, Boylston.

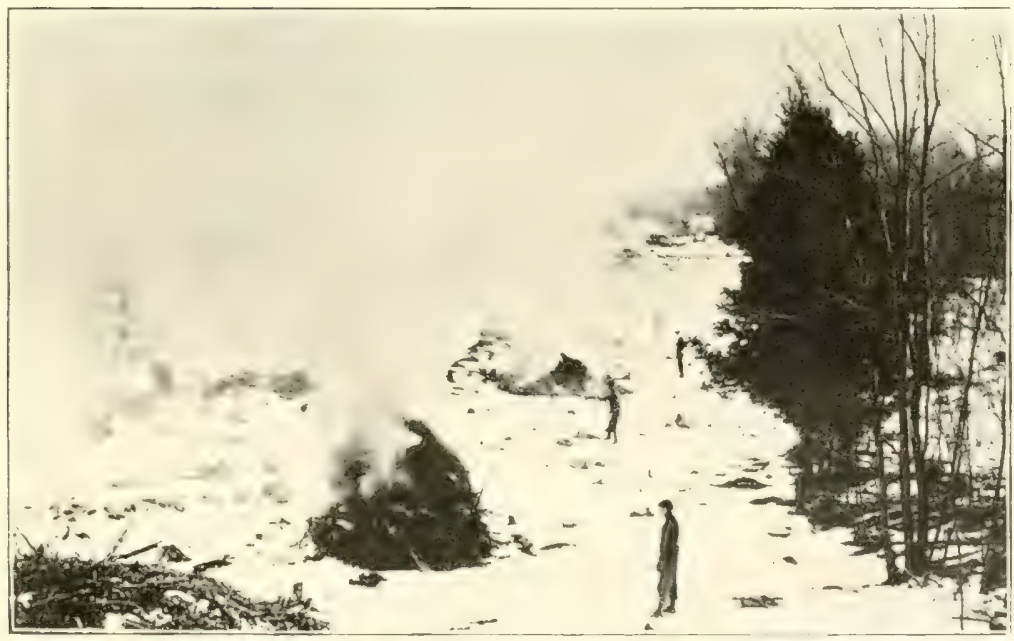

FIG. 20. - Burning brush along a tire line, work being done when the snow is on the ground, to prevent the fire from ruming. A trench six feet wide indis. tinctly shown on the left. 



\section{Reforestation Act of 1908 (Chapter 478).}

An Act to provide for the Purchase of Forest Land and for ReFORESTATION.

Be it enacted, etc., as follows:

SECTION 1. For the purpose of experiment and illustration in forest management and for the purposes speeified in section seven of this act, the sum of five thousand dollars may be expended in the year nineteen hundred and eight, and the sum of ten thousand dollars annually thereafter, by the state forester, with the advice and consent of the governor and council, in purchasing lands situated within the commonwealth and adapted to forest production. The price of such land shall not exceed in any instance five dollars per acre, nor shall more than forty aeres be acquired in any one tract in any one year, except that a greater area may so be acquired if the land purchased directly affects a source or tributary of water supply in any city or town of the commonwealth. All lands acquired under the provisions of this aet shall be conveyed to the commonwealth, and no lands shall be paid for nor shall any moneys be expended in improvements thereon until all instruments of conveyance and the title to be transferred thereby have been approved by the attorney-general and until such instruments have been executed and recorded.

SECTION 2. The owners of land purchased under this act, or their heirs and assigns, may repurchase the land from the commonwealth at any time within ten years after the purchase by the commonwealth, upon paying the price originally paid by the commonwealth, together with the amount expended in improvements and maintenance, with interest at the rate of four per cent per annum on the purchase price. The state forester, with the approval of the governor and council, may execute in behalf of the commonwealth such deeds of reconveyance as may be necessary under this section: provided, however, that there shall be included in such deeds a restriction requiring that trees cut from such property shall not be less than eight inches in diameter at the butt.

SECrion 3. The state forester may in his discretion, but subject to the approval of the deed and title by the attorney-general as provided in section one, accept on behalf of the commonwealth gifts of land to be held and managed for the purpose hereinbefore expressed. A donor of such land may reserve the right to buy back the land in accordance with the provisions of section two, but in the absence of a provision to that effect in his deed of gift he shall not have such right.

SECTION 4. Land aequired under the provisions of this act shall be under the control and management of the state forester who may, sub- 
ject to the approval of the governor and comneil, cut and sell trees, wood and other produce therefrom.

SeCtion 5. All moneys receired by or payable to the commonwealth or any one acting on its behalf under the provisions of this act shall be paid into the treasury of the commonwealth.

SECTIOx 6. Land acquired under the provisions of this act and subsequently reconreyed under the provisions of sections two or three shall not be exempt from taxation on account of any plantation of trees set out or planted while it was held by the commonwealth.

SECTION 7. For the purpose of assisting in reforestation a portion, not exceeding twenty per cent of the money authorized by this act to be expended may be used by the state forester for the distribution at not less than cost of seeds and seedlings to land owners who are citizens of the commonwealth, under such conditions and restrictions as the state forester, subject to the approval of the governor and council, may deem adrisable.

SECTIOX S. The state forester shall re-plant or otherwise manage all land aequired by the commonwealth and held by it under the provisions of this act, in such manner as will, in his judgment, produce the best forest growth both as to practical forestry results and protection of water supplies.

SECTION 9. Mll acts and parts of acts inconsistent herewith are hereby repealed.

SECTiox 10. This aet shall take effect upon its passage. [Approved IIay 1, 1908 .

The purpose of the above act is to place before the people an example along forestry lines which will aid them in carrying ont the work for themselves. For this reason it is desired that the State, as far as possible, take orer lots easily accessible to main highways.

In some instances lots have been taken over where it has been decmed adrisable to protect the plantations from forest fires by making a fire line, or making provision for some one in the near ricinity to be supplied with fire extinguishers and equipment for fighting fires, and to patrol the lot in exceedingly dry times.

$\Lambda$ number of lots have also been acquired where a small portion had some small growth which, if systematically thinned, could be profitably handled (Fig. 22).

Private parties owning land in the State adapted for reforestation purposes should make application to the State Forester, who will gladly fumish advice along forestry lines. 


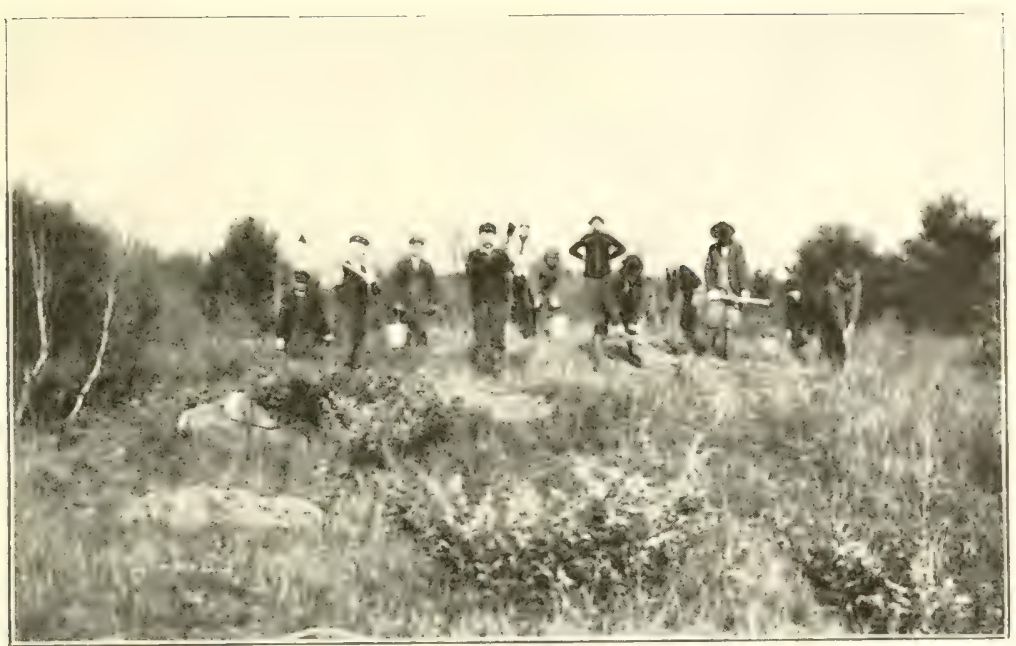

FIg. 21. - A planting gang at work under the reforestation act,

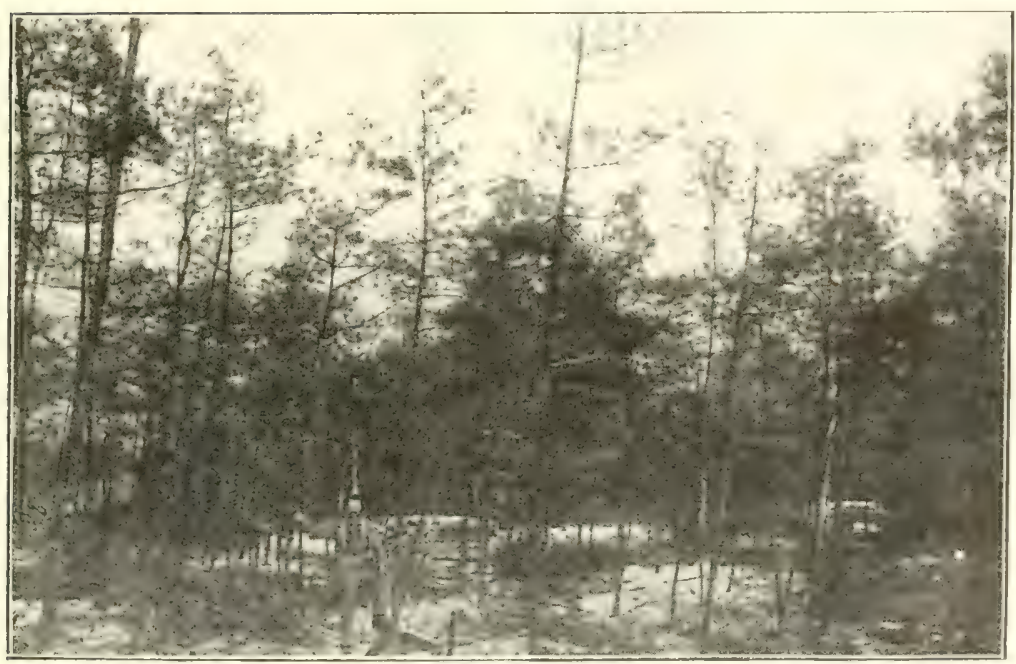

FIG. 22. - View of example in thinning, where undesirable hardwoods have been removed and put into corl wood, to give the undergrowing stand of white pine a chance to grow. 



\section{SYLVICULTURAL CHARACTERISTIUS OF TREES.}

Trees most commonly found growing in Massachusetts, the Uses to which their Timber is put, and a Few of their Most Important Enemies.

For convenience in the matter of reference, we shall separate the different species under three heads: (1) conifer's, (2) northern hardwoods and (3) southern hardwoods, the term " hardwoods" being used for all trees other than conifers.

Under (1) will be treated white pine, red or Norway pine, pitch pine, Scotch pine, hemlock, red spruce, and Norway spruce.

Under (2) come rock maple, beech, white birch and yellow bireh.

Under (3), chestnut, red oak, white oak, red maple, shagbark hickory, black locust and white ash.

\section{Conifers.}

\section{White Pine (Pinus strobus).}

This species is placed first, both because of its marked adaptability to growth in this Statc and becanse of the universal demand for its lumber.

It may be found growing in all sorts of situations except in extremely wet soil, such as swamps. This does not, of course, mean that the tree grows equally well everywhere, for it undoubtedly prefers a well-drained, loamy sand, and there reaches its best development. Ideal conditions exist on the slopes and at the lottoms of the old glacial deposits so numerous all over the State.

The white pine grows either pure or in mixture with other species. but in the latter case the other trees should form a lower or under story about the pine, otherwise, the tree will not grow well, being too much shaded by the others. It is a mistake to believe that white pine is a shade-enduring tree, for, while some shade is beneficial in the early stages of growth, it is very harmful at later periods.

Reproduction is by seed, which is produced annually, but in much larger quantities at intervals of from five to six years, 
called "seed years." The seeding process is described in detail elsewhere in this bulletin.

As regards size and rate of growth, white pine compares favorably with any eastern tree and far exceeds most of them in these respects, reaching merchantable size in about fifty years, as shown in the "Forest Mensuration of the White Pine in Massachusetts," published by the State Forester in 1908. If left to grow undisturbed, it reaches a size excelled only by trees of the Pacific coast, specimens having been recorded that exeeeded 200 feet in height, with a diameter of 6 feet, while heights of 100 feet, with :

The chief enemy of this tree, as of all other's in this State, is fire, which, if it does not kill, so weakens it as to render it liable to attack by all kinds of insects and fungi. The white pine is especially susceptible when young, even a slight ground fire being quite sufficient to completely kill it. In this respect it resembles the chestrut.

Leading insect enemies are the pine weeril and the various bark borers, all of which are much less likely to cause trouble in healthy stands than in those weakened by other canses. 'The gypsy moth, while it will eat pines as well as everything else, is not apt to invade pure stands containing this species alone. The brown-tail and leopard moths do not eat pine.

It seems almost unnecessary to enmmerate the nses of the tree, as they are so well known. Among them may be mentioned building timber of all kinds, laths, various kinds of cabinet material, interior finish, wooden ware, matches, flag poles, masts and boxes.

\section{Red or Tomway Pine (Pinus resinosa).}

This tree, while common in southern Maine, is not so familiar to residents of Massachusetts, partly because it does not grow in pure stands, but only as scattered individuals, and partly because the difficulty of collecting the seed renders the cost of planting either seed or seedlings very high. The tree, however, is a very excellent species, and compares farorably with white pine in many respects.

It grows on the same kind of soil as the white pine, but will grow on dry ridges, where the white pine will not. It will not grow in swamps or in poorly drained soil. 
It associates usually with white pine, growing in scattered groups throughout the stand. More rarely it is found in company with hardwoods, such as oaks and birches.

Red pine is a rather poor seeder, not beginning to bear until about twenty-five years old, and then giving only light crops at four or five year intervals. The seed will not germinate in thick grass or sod, and the seedlings require much light. A bare mineral soil containing some moisture is best. The percentage of germination is high.

In rate of growth red pine is more rapid than white, especially when young, though it is more short-lived in the long run. It reaches a diameter of 23 inches and a height of 80 to 90 feet in one hundred and twenty-five years, producing merchantable timber. Sixty years will produce good small stock.

No serious insect pests or fungous diseases attack this species, and it is remarkably free from rot. Light ground fires do not injure it so much as they do white pine, especially as the tree grows older.

The wood is used for general construction, bridge timbers, shipbuilding, ear construction and flooring.

\section{Pitch Pine (Pinus rigida).}

This tree grows on dry sandy soils, and is especially suited to planting in such localities. When pure it forms very thin stands, owing to its extreme intolerance, and it must be above all other species in mixture, or it will die.

It is a prolific seeder, and succeeds well under the above conditions, and is also a fairly rapid grower, reaching at times a height of 80 feet and a diameter of 30 inches.

It is not subject to attack by insects or fungi, and is probably the most resistant to fire of any conifer in Massachusetts, surviving repeated burnings.

The wood is used largely for fuel, being brittle and not strong.

\section{Scotch Pine (Pinus sylvestris).}

This tree is the common pine of northern Europe, oceupying there the same place that the white pine does in this country as a timber tree. Its growth, however, more closely resembles 
our Norway, both in quality of lumber and in the lind of soil preferred by the tree.

It difters, howerer, in the fact that it grows well in dense pure stands rather than in mixture with other species, and also in that it seeds often and abundantly, and therefore costs much less to grow than red pine.

In common with the other pines, Scotch is not much subject to disease and insect attack, but is somerhat more sensitive to fire than red.

It is used for the same purposes as red pine.

\section{Hemlock (T'suga americana).}

'This tree, easily the most tolerant of the American conifers, prefers cold north and east slopes of the hillsides in the northern parts of the State. Because of its extreme tolerance, it will grow either with any other speeies, evergreen or hardwood, or in dense prue stands in all stages of growth.

The seeds are borne in very small cones, and are very light. Reproduction is good under favorable conditions of soil and location, and the tree frequently grows apparently out of bare rock, so thin is the soil.

Trees of this species often grow to a rery large size, but such indiriduals are apt to he rotten and shaky. Other species will not grow under hemlcek because of the dense shade cast by it.

The wood is being used more and more for building timber, as the supply of other species grows scarcer, and some lumber dealcrs prefer it to spruce for rough frame timbers. If care is not used in drving it is rerr likely to check.

\section{Red Spruce (Picea mura).}

This tree is the timber spruce of Mraine, and is now the most important species in that State in size of cut. It will grow in northern Massachusetts on the higher elerations, preferably in mixture with pine and hemlock.

It will grow in the shade of other trees for many years, and shows marked ability to start up and grow when suddenly exposed to the light.

Growth is not rapid, and large size is not reached by this 
species; but good, straight timber is produced, which finds a ready maiket. The limbs do not drop off readily, however, and clear timber ean therefore be grown only in dense stands.

The tree reproduces itself well when the leaf litter on the ground is not too thick, and the seedlings therefore start readily under the mature trees of the same species, forming a stand containing trees of all ages.

The principal enemy is the spruce bark beetle (Dendroctonus piceaperda).

The uses of the wood are well known; building timber, piano sounding boark, inside finish, claploards, and in Maine pulpwood, are among them.

\section{Norway Spruce (Picea excelsa).}

This is one of the principal timber trees of Europe, and is strongly recommenterl for planting in this enuntry, posessing, as it does, all the advantages of the red with the added one of being a much more rapid grower.

\section{Northern Hardwoods.}

\section{Rock Maple (Acer saccharum).}

This tree, known also as the sugar maple, is one of the most important of our northern hardwoods, both for sugar and timber. It grows usually in mixture with beech, oaks, ashes, etc., as well as conifers, but may grow in pure stands.

Its chief sylvicultural feature is its extreme tolerance, making it the mut shadc-learing of all American hardwoods. with the possible exception of beech. A deep, moist soil is necessary for good growth.

Seed is produced almost every year, but full seed years occur only at intervals of from three to five years. The percentage of germination is rather low, but this is offset by the ability of the young trees to stand dense shade.

Growth is slow, but persists for a long time, the tree reaching a height of 70 or 80 feet and a diameter of 2 or 3 feet. The tree is not very wind-firm.

Rock maple is not very susceptible to injury by fire or fungi, though a good deal of damage is sometimes done by the forest 
tent caterpillar, which strips the foliage from the tree and so reduces its vigor. Another enemy is the "saddled prominent" (Heterocampa guttivitta), which has caused a great deal of damage in Maine and New Hampshire, but is now being brought under control by natural enemies.

\section{Beech (Fagus ferruginea).}

This tree is conceded to be the most tolerant of all the hardwood species found in Massachusetts; that is, it will grow well beneath the most dense shade, provided the soil is suitable for germination, and not only this, but it requires shade in order to start at all. It grows best on rich, loamy soil, on cool slopes, in mixtures with other hardwoods, such as the oaks, chestnut and maple. It sometimes forms pure stands with here and there scattering pine and hemlock.

The nuts are so much liked by squirrels that reproduction is hindered by these animals.

The beech is a rather slow-growing tree, generally owing to the dense shade which surrounds it; but it reaches good size, both in height and diameter.

The principal enemy in Massachusetts may be said to be the "saddled prominent," previously mentioned, which prefers the leares of this tree to all others, thus causing the woods to resemble winter in the height of the growing season.

The wood forms one of our most valuable hardwoods, and is used for tool handles, furniture, flooring and in turnery.

\section{White Birch (Betula papyrifera).}

This tree is to be rigidly distinguished from the grey birch (sometimes called "white") so common in this State. The latter species (Brtula populifolia) is practically valueles for all purposes, fuel included, and must not be confused with the white, which forms a valuable timber tree.

White birch grows on northerly slopes, in mixture with other hardwoods, pine and hemlock. The seed is very light, favoring reproduction by the wind, and cansing the propagation of the species orer burned areas when there is enomgh soil moisture to support tree growth. The tree will not stand shade, being 
very intolerant, and the seed will not germinate on a thick layer of humus, so that reproduction within the roods is unlikely.

A long, clear bole is developed by growth in the forest, the tree reaching a height of 70 to 80 feet in sixty to serenty-fice years. It is a short-lived tree, seldom living over one hundred and twenty years when grown from seed; sprouts do not live over ninety years.

Its most serious enemy is fire, since it is not subject to attacks by insects, fungi or windfall.

The wood is used, to the practical exclusion of all others, in the manufacture of spools, shoe pegs, shoe shanks, and very largely for toothpicks, dowels, bubbins, shuttles and rarious toys and novelties.

\section{Yellow Birch (Betula lutea).}

This tree is quite commonly found in Massachusetts in mixture with evergreens and decidnous species, where it is distinguished by its yellow, shiny bark, usually of a tattered appearance.

It is a valuable species for ship building, furniture and wheel hubs, having a very fine, clear texture of grain.

It is mentioned in this list not because we desire to urge planting this species, but in order that owners may recognize it as a valuable tree, and not of the same class as the grey birch, which, of no value in itself, usually causes more or less injury to its neighbors by interfering with their proper development.

\section{Southern Hardwoods.}

Chestnut (Castanea dentata).

This tree, like the oak, reaches its best condition on the lower slopes of hills, or in cores where the soil is rich, moist and fairly deep. It will grow, however, on a very thin soil, if it be loamy. It grows much more rapidly than the oaks, attaining saw $\operatorname{lng}$ size in about fifty years. Under favorable conditions it will attain a height of 100 feet and a diameter of 3 or 4 feet. As a sprout its growth is remarkable, excelling that of any deciduous tree except poplar. 
It bears a crop of seed each year, but the crop varies in abundance.

The tree is quite intolerant, but, as it grows more rapidly than the other hardwoods with which it associates, it has little trouble in getting all the light it wants.

The chestnut, in common with the hardwoods, is of course eaten by the grpsy moth, but it has few insect enemies peculiar to itself. It is, however, gravely affected by a fungus called the chestnut bark disease (Diaporthe parasitica), which has killed practically every chestnut tree within twenty miles of New York. The tree is severely injured by fire, on account of the lightness and inflammability of its bark.

The rood is light, stift, strong, and rery durable in contact with the soil. It is used for ties, poles, building material, posts, slack cooperage and furniture. The wood is distilled, and produces a tanning extract used in the place of tan bark. The cut of chestnut has increased nearly 100 per cent. in the past decade.

\section{The Oaks, White, Red and Black.}

For their best development our native oaks require a rich, moist soil, situated in cover or on the lower slopes of a hill. With the exception of the swamp white oak, they will not grow on wet land; and, on the other hand, they make a fair growth on the top of dry, exposed ridges.

They require considerable sumlight for their best development, but the black and red oaks will stand some shading. The white oak is quite intolerant.

The white oak bears seed nearly every year, but the trees of the black oak family require two year's to mature the acorns.

The oak is a slow-growing tree, requiring at best serenty-five years to obtain a tree of saw log size. The black and red oak grow more rapidly than the white in early youth, but the white oak maintains its growth for a longer period, so that at the age of maturity there will be little to choose between them as to size.

Brown-tail and gypsy moths seem to be particularly fond of oaks, but, as they eat other species very readily, this preference is not of great importance. The "saddled prominent" (Hetero- 
campa guttivitta), an insect now doing a large anount of damage in northern New England, is known to eat it at times. The oak is unusually free from borer's and bark beetles, and is quite resistant to damage by ground fires.

Oảk wood is heavy, hard, tough, close-grained and very durable. White oak has these qualitics to a greater degree than the red and black. The wood is used extensively in ship building, tight cooperage, vehicle manufacture, farm implements, ties, interior finish and furniture. So great is the economic value of this wood that the available supply is being rapidly exhausted.

\section{Red Maple (Acer rubrum).}

This tree is partial to wet land, and is our typical swamp tree, growing pure or in company with ash, hornheam and hemlock. Like other swamp-land trees, it is very tolerant of shade, although in this condition its growth is slow.

It bears an abundance of seed each spring.

Under forest conditions it seldom attains a height of more than 60 feet and a diameter of nore than 15 inches. It grows quite rapidly when young, but slacks materially when about thirty years old.

It is not attacked so readily by gypsy and brown-tail moths as are most of the other hardwoods.

The wood is lighter, not as strong and more subject to decay than is hard maple, but is sometimes nsed as a substitute for it.

It is not a tree that is recomwended for forest planting.

\section{Shagbark Hickory (Hicoria ovata).}

This tree is of increasing importance hecause of its increasing scarcity, due to the heavy demand for hickory wood, - a demand caused by its unrivalled good qualities for certain kinds of construction.

It is primarily a tree of fresh, fertile soils and rich situations along streams, and produces good wood in clay soil.

It is never found pure to any great extent, but always in mixture with other species, and, being very tolerant, will grow well in the shade of the others.

Seed is borne in a fairly prolific manner every two or three years, but the nuts are largely eaten by weevils and squirrels. 
Growth is not very rapid, but is extremely persistent, the tree living to an age of two hundred to two hundred and twenty-five years, in full vigor. Timber trees are produced in about one hundred years.

The wood is used for rehicle construction, handles of axes, etc. It is the strongest of the hickories except pignut, and should be favored orer that species except on dry soils and where there is no market for the nuts.

\section{Black Locust (Robina pseudacacia).}

The black locust is a more southern species, but will grow in Massachusetts, and is recommended where a quick-growing tree is desired. It demands plenty of light and a mineral soil, and produces its best wood at forty to fifty years, reaching only some 60 to 70 feet in height. The seed is borne in pods, and if left in them preserves its germinating power for several years. Seedlings grow best when raised in the nurscry for one year.

The wood is heary, exceedingly hard and strong, very durable in contact with the soil, and is used in ship building, turnery and construction. It is preferred for tree mails, and makes good railroad ties.

\section{White Ash (Fraximus americana).}

This tree prefers to grow on rich, moist bottom lands, where it will be found mixed with elm, basswood, yellow birch and maple. It will grow in a wet swamp and equally on dry, exposed ridges, so that it may be said to be versatile in habit.

It is quite tolerant when young, but when too much shaded its diameter growth is very slow.

Some seed is produced each Fear, but abundantly only once in three years. It is quite easy to collect, and the tree is therefore one used quite extensively in forest planting.

The rate of growth is rapid when compared with that of most of the associated hardwoods, but it varies considerably according to conditions of moisture and situation. Post timber may be obtained from it in from fifteen to twenty years.

White ash is attacked by a number of fungous diseases, which injure the leaves and flowers, but not sufficiently to kill the trees. It has the distinction of being the only deciduous tree 
which the gypsy moth does not attack, although there have been cases where this pest has attacked this tree when everything else was gone.

The wood is tough and elastic, and this, combined with its ability to take a good polish and to seasun withent injury, makes it a timber of exceptional value for furniture, car vehicles, manufacture, interior woodwork, agricultural implements and tools.

Plantations will do best in a protected valley on a light loam. 
No........

Received.
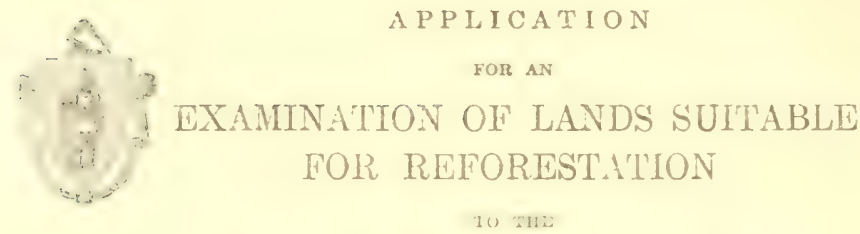

MASSACHUSETTS STATE FOIRESTER, 6 BEACON STREET, BOSTON.

The State Forester is empowered, under chapter 478, Acts of 1908, to accept, on behalf of the Commonwealth, gifts of land to be held and managed for the purpose of experiment and illustration in forest management and for reforestation.

The owners of land acquired under this act, ol their heirs and assions, may redeem the land from the Commontrealth at any time within ten years, upon payment to the Commonwealth of the amount expended in improvements and maintenance; provided, however, that there shall be included in the deed of reconveyance a restriction requiring that in the future the eutting of trees on this land shall be in accordance with modern forestry methods.

"SECTION S. The state forester shall re-plant or otherwise manage all land acquired by the Commonwealth and beld by it under the provisions of this aet, in such manner as will, in his judgment, produce the best forest growth both as to practical forestry results and protection of water supplies."

Upon receipt, this request will be placed on file, and you will be informer, in order of application, approximately when the examination can be male, and a mutual date can then be decided upon.

It is always more satisfactory to personally meet on the property the umer or party most interested. In this way a definite understanding ean be had as to future undertakings.

Then sending in this application, a brief deseription of the land will assist us.

With the above understanding, I desire to have an examination made of a tract or tracts of land of approximately............. acres, located

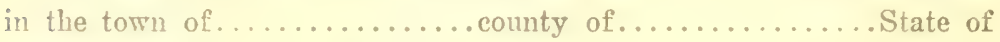
Massachusetts.

\section{Signed}

\section{Address}

Date. 


\section{Reforestation 충}

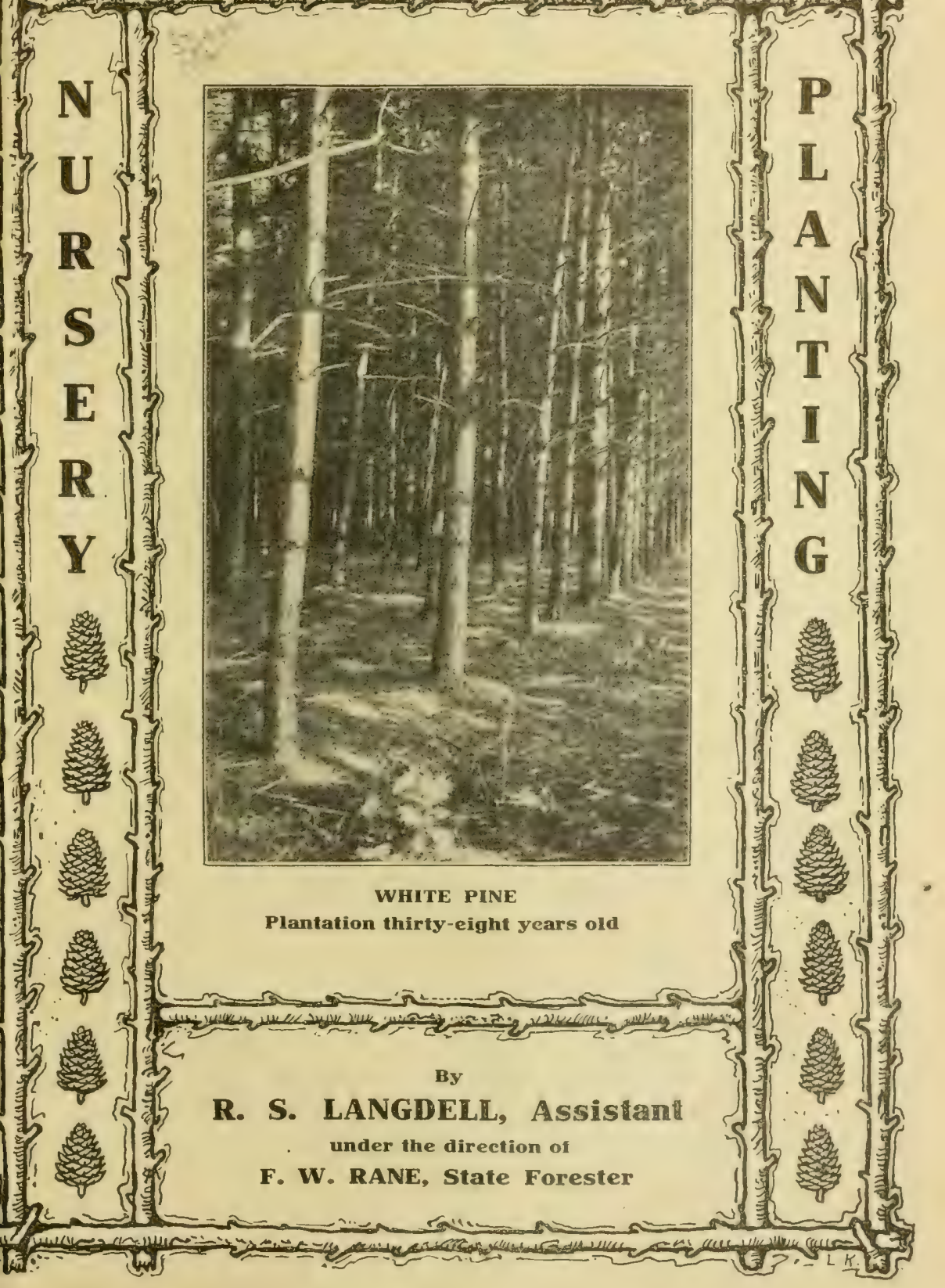









\section{LIBRARY OF CONGRESS}

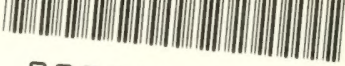
00008971755 